\title{
Coastal Tourism in Montenegro - Economic Dynamics, Spatial Developments and Future Perspectives
}

\author{
Matthias Bickert, Daniel Göler, Holger Lehmeier
}

\begin{abstract}
Montenegro seeks its future perspectives in tourism. And there are good reasons for that: The country was considered to be the fastest growing tourism market worldwide in 2007. Notwithstanding a slight decrease during the last years, tourism is still seen as a crucial factor for future economic development. This seems to be a viable option if we consider Montenegro's natural potential, its beneficial position on the Adriatic coastline and the experience in tourism gained in the many years since the 1970s.
\end{abstract}

These dynamic developments were motivation enough to explore tourism in Montenegro in a research project with strong empirical evidence, organised as co-operation between Universities from Germany, Albania, Montenegro and Serbia. Our empirical approach included semi-structured, flexible interviews with different types of stakeholders. Since tourism in Montenegro is still almost entirely limited to the coast, we chose three coastal hot-spots in tourism, namely Kotor, Budva and Ulcinj.

Our results show that the current development in tourism can surely be considered as progressive and dynamic. But it is also strongly affected by multiple polarisations and divergent trends. There is a need for infrastructural upgrades in the mass tourism sector, which is for the most part a low budget market with very difficult future perspectives. At the same time, there is a small but growing number of very exclusive offers, often seen as the vanguard of Montenegro's future as an upper class tourists' destination. All in all, the economic bias towards coastal tourism involves the risk of an increase in the already strong spatial disparities, leaving behind a mountainous hinterland with a shrinking economy and population.

Key words: economic development, tourism, Montenegro

\section{Obalni turizam u Crnoj Gori - razvojna dinamika, prostorni razvoj i buduće perspektive}

Crna Gora traži svoju budućnost u turizmu, i to s dobrim razlozima: u 2007. godini bila je najbrže rastuće turističko tržište u svijetu. Unatoč blagom padu posljednjih godina, turizam se i dalje smatra najvažnijim faktorom budućeg ekonomskog razvoja države. To i ne čudi, uzmu li se u obzir prirodne karakteristike Crne Gore, položaj na obali Jadranskog mora i iskustvo u turizmu koji započinje još 1970-ih.

Ovakav dinamičan razvoj bio je glavni razlog za istraživanje turizma Crne Gore putem znanstvenog projekta nastalog u suradnji sveučilišta iz Njemačke, Albanije, Crne Gore i Srbije. Empirijski pristup u ovom istraživanju uključuje polustrukturirane, fleksibilne

Please cite this article as: Bickert, M., Göler, D., Lehmeier H., 2011: Coastal 
intervjue s različitim dionicima. S obzirom da je turizam Crne Gore vezan gotovo isključivo uz obalu, odabrana su tri obalna turistička centra - Kotor, Budva i Ulcinj.

Rezultati pokazuju da je razvoj tržišta turističkih usluga u Crnoj Gori dinamičan i napreduje, dok je istovremeno karakteriziran jakom polarizacijom i divergentnim trendovima. Potrebna su ulaganja u sektoru infrastrukture koja je većinom orijentirana na masovni turizam i tržište niske platežne moći kojem je razvojna budućnost neizvjesna. Istovremeno, postoji malena, ali rastuća ponuda ekskluzivnih turističkih usluga koje se smatraju predvodnicom budućeg razvoja Crne Gore kao destinacije za bogate turiste. Sve u svemu, gospodarski naglasak na razvoj obalnog turizma uključuje i rizik povećanja već snažnih prostornih dispariteta, ostavljajući za sobom planinsku unutrašnjost s padom u gospodarskom razvoju i populaciji.

Ključne riječi: ekonomski razvoj, turizam, Crna Gora

\section{INTRODUCTION}

"Tourism is Montenegro's Future" - this statement is not only popular among local entrepreneurs in the tourism sector of this small Balkan state, it is also a common opinion in various scientific publications (e.g. contributions in Ministarstvo Turizma Crne Gore a. Turistička Organizacija Crne Gore 2004). The economic perspectives of the country with its 630,000 inhabitants (according to the 2003 census) seem to be clearly defined. Montenegro was confronted with severe problems during the transition period, which resulted in the almost complete decline of its industrial production. Now, Montenegro is seeking its future in the tourism sector. There are many good reasons for that. Montenegro's natural potential and the beneficial position on the Adriatic coastline have led to the development of mass tourism since the 1960s. In the 1970s and 1980s, the tourism industry was growing rapidly on the Yugoslavian coastline, similar to the situation in Spain at that time (Gosar 2007, p. 129). These dynamic processes were affected adversely after the disintegration of Yugoslavia in 1991/1992 and during the following wars (Jordan 2005a, 701ff.). To gain back the lost position on the global tourism market, the tourist destinations of the eastern Adriatic have to accomplish a lot. Hall $(2004,344)$ names "reconstruction, diversification and re-imaging" as the most important tasks for the next years. Until 2000, there was only a moderate revitalisation of Montenegro's tourism (Büschenfeld 2001, 52), much less than e.g. in Croatia. But since the turn of the millennium, tourism is growing fast again. Even more than that, in 2007 Montenegro was the fastest growing tourism market worldwide (Mildner 2009, 13). Of course, this includes all the positive and negative implications. There are enormous economic potentials but there is also the risk of economic monostructuring and growing spatial disparities.

Although tourism is commonly seen as one of the key factors for economic development, not only in Montenegro but also in other South-East-European countries, the number of state-of-the-art research papers in international languages is surprisingly low. Especially in the field of geographical research on transition, the topic of tourism is vastly under-represented. The contributions of Jordan (2005b) on Croatia and Light (2006) on Romania are rare exceptions. In the case of Montenegro, up-to-date research is lacking. 
As tourism is the main field of development for this country, this constitutes a major desideratum for geographical research and serves as motivation for a project with strong empirical evidence.

As a consequence, the main resources for information besides our own collected data are official publications such as governmental sheets or MONSTAT and WTTC for statistics. Furthermore the "Tourismus-Masterplan Montenegro" from the "German Society of Development (DEG)" can be considered as a major source.

\section{METHODOLOGY}

The article aims to provide an AMSWOT-profile (showing "achievements, mistakes, strengths, weaknesses, opportunities and threats"). Apart from using official statistics and scientific literature, we base our conclusions on empirical evidence gained during geographical field trips to Montenegro in 2009. We used a stakeholder-approach and concentrated on the providers in the tourism industry. Thus, 63 semi-standardised interviews were conducted with hotel owners, private entrepreneurs of all kinds, and responsible persons in tourism agencies and public administration. As places for local and detailed studies, three hot-spots (Kotor, Budva and Ulcinj; Fig. 1) of Montenegrin tourism were chosen. Thus, the range of different tourism destinations can be covered: Kotor has a well preserved historical city and a unique position in the Kotor Bay, which is listed as a UNESCO World Heritage Site. The city is part of international cruiser shipping routes and serves as a destination for high-priced heritage tourism. Budva also has a historic city centre - generally comparable to Kotor or Dubrovnik. But the main motive of the many

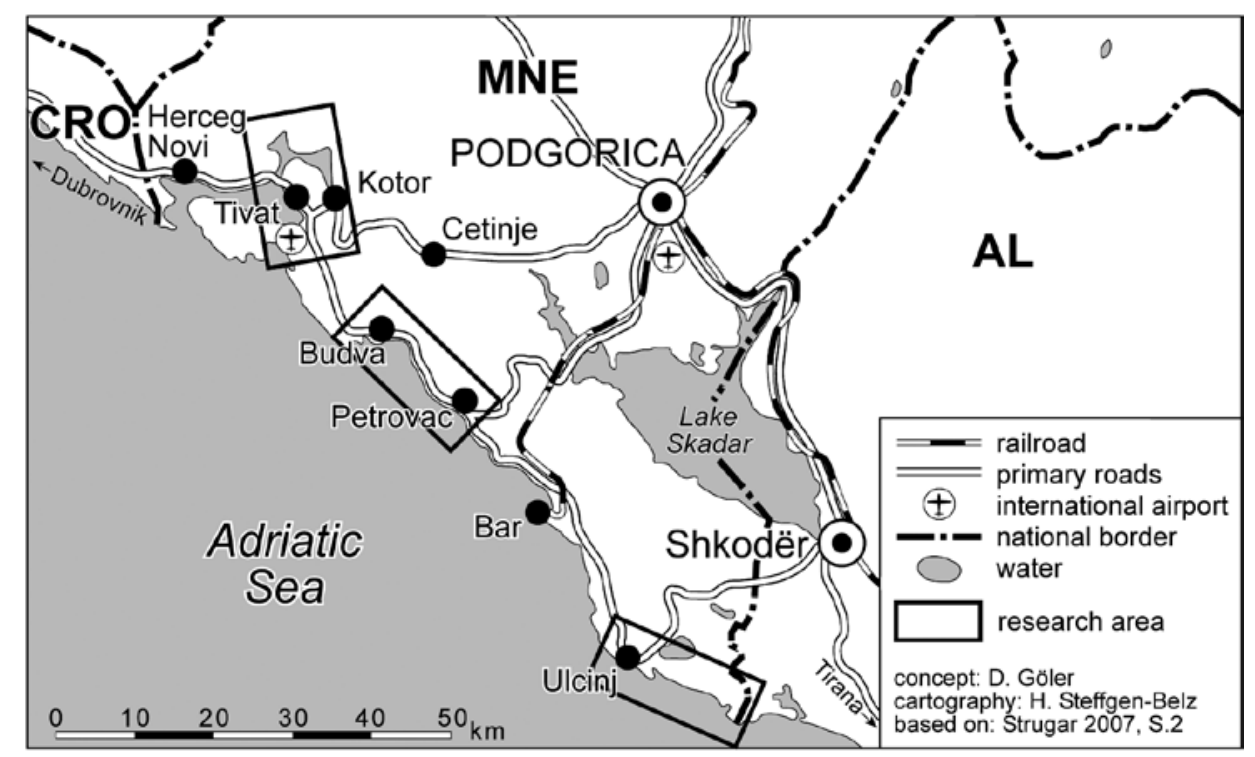

Fig.1 Overview of Montenegro's coastline

Sl. 1. Crnogorska obala 
tourists coming here is typical sun\&beach-tourism with a narrow season. This is also true for Ulcinj in southern Montenegro, where the local population belongs mainly to the Albanian ethnicity (Bottlik 2008, 57). There, many tourists from Albania and Kosovo spend their holidays close to the narrow city centre.

Our study is confined to Montenegro's coastal region. Winter-sports and hiking tourism in the hinterland were not part of our research. But since over $90 \%$ of all tourist arrivals are registered in coastal resorts, this still covers the major part of the nationwide tourism.

\section{CURRENT DEVELOPMENTS IN MONTENEGRO'S TOURISM}

After the 1990s, it became clear that Montenegro's tourism industry needed major restructuring. Thus, the German Ministry for Development was appointed to develop a "masterplan for tourism in Montenegro" (DEG 2001). Due to structural shortfalls in the tourism market, a disillusioning picture was drawn in the project's final report: The State's financing power was too low, the tourism product could not cope with the market and the employees were not sufficiently trained. All this led to a dramatic decline in overnight stays - from about 11 million in the late 1980s to 5 million at the beginning of the $21 \mathrm{st}$ century (DEG 2001, 2).

First and foremost the international demand, which had had major importance in the 1980s, dropped to almost zero. Instead, many tourists came from the temporarily isolated Serbia, so that beaches were no less crowded than before. But the majority of these tourists were less financially strong, which caused a steadily decreasing price level (Jordan 2006, 51). Additionally, the season remained very short, being limited to a few weeks in late summer.

The masterplan points out clear strategic goals to achieve long-lasting competitiveness in the tourism sector: On the one hand, the Mediterranean sun\&beach tourism has to be improved concerning its quality, so that Montenegro can compete with other destinations around the Mediterranean Sea. On the other hand, special offers during the winter months should be developed. Thus, the region could be interesting for certain target groups, even outside the main season (DEG 2001). In the years since 2000, Montenegro's tourism sector grew quite rapidly, while three major developments can be identified:

\section{Renaissance of tourism in the 21st century}

The value added from tourism has been constantly rising since the turn of the millennium (Fig. 2). The turnover in private tourism almost tripled between 2004 and 2009, when it changed from $€ 67.4$ million p.a. to $€ 189.1$ million. In 2006 and 2007 annual growth rates reached $25 \%$ and more. Since 2007 , the growth rate has slowed down notably - even dropping to a negative growth rate in 2009. While this is often seen as a consequence of the global economic crisis, optimistic forecasts see a slight recuperation with moderate positive growth rates for 2010 (WTTC 2010; Fig. 2). With the overall increased revenue in the tourism industry, its relative importance for the Montenegrin economy as a whole increased as well. According to an estimation of the World Travel \& Tourism Council, the sector of tourism and recreation is contributing $20.3 \%$ to the national GDP. There are 


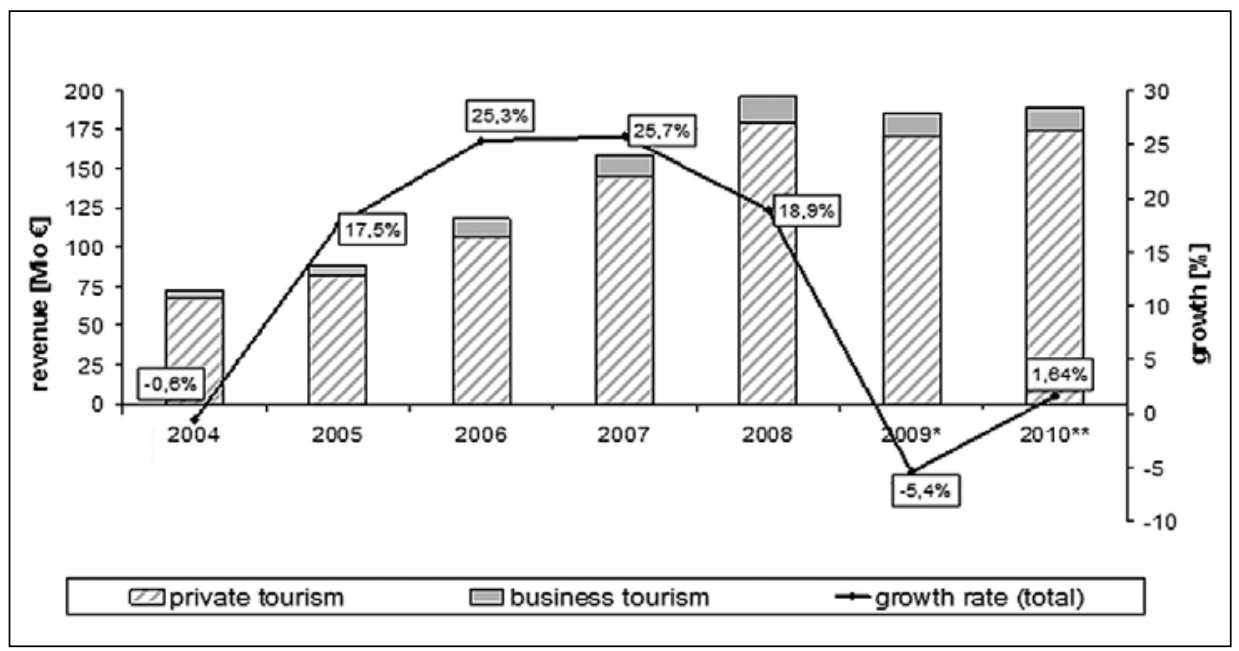

Fig. 2 Growth and revenue of Montenegrin tourism 2004-2010; Data source: WTTC 2009; WTTC 2010 (* Estimate for 2009; ** Forecast for 2010)

Sl. 2. Rast i prihodi turizma Crne Gore od 2004. do 2010. godine. Izvor: WTTC, 2010. (Procjena za 2009., prognoza za 2010.)

around 30,000 jobs in the tourism industry and its neighbouring sectors, which corresponds to $18 \%$ of Montenegro's workforce (WTTC 2010, p.3).

\section{Change in demand}

The number of foreign - non-Serbian - tourists has been increasing since the end of the 1990s. In the year 2000, this group accounted for about 430,000 overnight stays ( $14 \%$ of all overnight stays in that year). In the same year, 1.8 million overnight stays of Serbian tourists were recorded, which corresponds to $58 \%$, while 911,000 overnight stays of Montenegrin citizens added a considerable 27\% (Crna Gora Ministarstvo Turizma i Zaštite Životne Sredine 2008, 17).

By 2007, these relations changed completely (Fig. 3). Though the absolute number of Serbian tourists increased again in this period - reaching 2.6 million overnight stays - its relative importance dropped to $36 \%$. The biggest share is now contributed by foreigners, which had 3.8 million overnight stays, corresponding to 52\%. Most of these tourists came from Russia and Bosnia-Herzegovina. The number of overnight stays of domestic people fell slightly to some $12 \%$ (MONSTAT 2009).

\section{Predominance of coastal tourism and limited seasonality}

The composition of the tourists visiting Montenegro has changed, but the dominant destinations have stayed the same. Tourism in Montenegro is still basically "sun\&beach" 


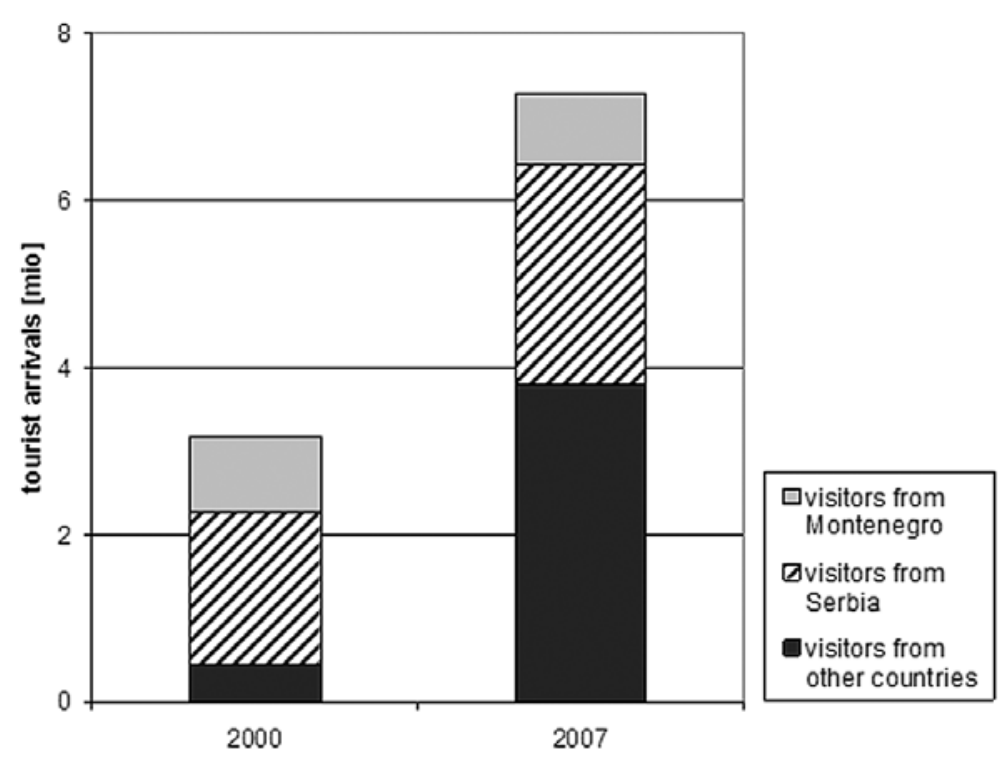

Fig. 3 Change in tourists' origin; Data Source: Crna Gora Ministarstvo Turizma i Zaštite Životne Sredine 2008, 17; MONSTAT 2009.

Sl. 3. Promjene u strukturi turističkih dolazaka prema državama. Izvor: Ministarstvo turizma i zaštite životne sredine Crne Gore; MONSTAT 2009.

tourism. There are possibilities for other types of tourism - be it winter-sports or rural tourism in rather peripheral areas (Winterhagen 2008). But in quantitative terms, these alternative forms of tourism are hardly significant. The coastal resorts still account for $89 \%$ of all tourist arrivals and $95 \%$ of all overnight stays. As a consequence, the season is very limited and concentrates mainly on July and August (Crna Gora Ministarstvo Turizma i Zaštite Životne Sredine 2008, 16).

\section{PRIVATISATION AND COMPETITION}

Due to its concentration on coastal tourism, Montenegro competes directly with other Mediterranean destinations. However, most of them lack the experiences of the socialist period. How does Montenegro handle this aspect of its Yugoslavian legacy? Many of the big hotels of that era survived the years of crisis during the 1990s and can still be found in central locations of many coastal settlements. At the time they were built, they were seen as the epitome of vital and prosperous tourism development. Now, most of them seem to have only poor future prospects.

Many examples for this type of "Yugoslavian" hotel can be found. Details may vary, but the big picture is quite similar. Most of them are still State-owned and are lacking needed investments for renewal or even maintenance. They cannot meet the standards necessary for middle or high-class tourism and have been unable to maintain their (once quite high) quality level. Even in high season the price-level is moderate, out of season it 
is very low. There are still well-trained employees from the "good old times" remaining, but the personnel management as a whole is utterly ineffective. All in all, the low standard of these hotels is severely reducing their cost-effectiveness.

Structural problems are followed by insufficient demand. This triggers a vicious circle that is ultimately leading to market failure. Even if one of these hotels is operating successfully (e.g. if it is almost completely booked during the season), the low prices prohibit the creation of resources necessary for future investments. It is quite clear that these older "Yugoslavian"-style hotels are generally not suitable for development towards high class tourism.

For this purpose, a number of new facilities have been created. The most important target group for them is the international "jet-set", demanding high standards but also able to pay high prices. In this respect, Montenegro seeks to compete with other, well-established destinations for the rich. Its two main advantages are supposed to be the relatively low prices and the exotic image.

Today, some high-class hotels (though only one 5-star establishment and several 4-star hotels) can be found along the coastline. The historical old town of Kotor hosts two of these, which were renovated and expensively re-designed during recent years. But due to the limited space within the protected heritage site of the city, they only provide a small number of beds. Most of the wealthier tourists visiting Kotor do not stay overnight anyway; they usually come to Kotor as part of a larger cruising-tour and go back to their ship after a couple of hours (Fig. 4).

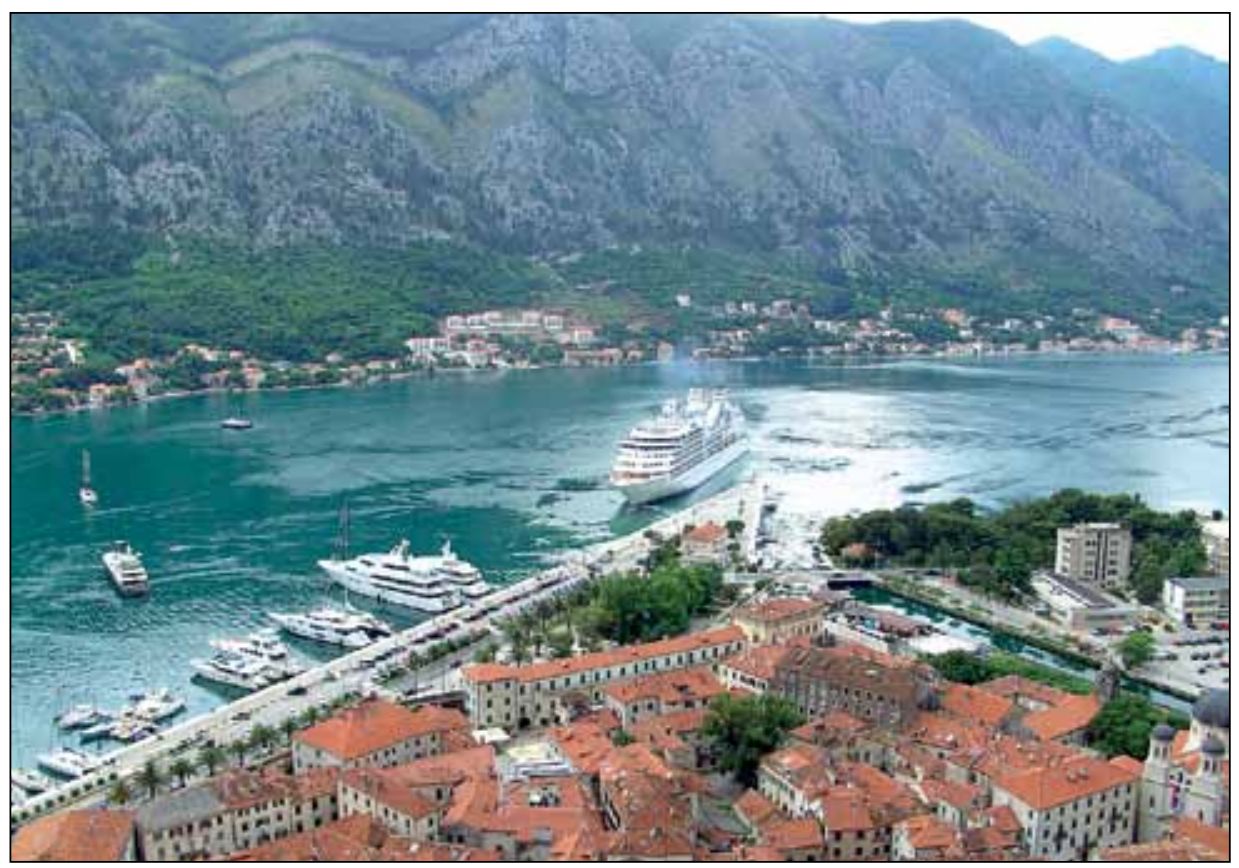

Fig. 4 Cruiser berthing in Kotor; Photo: H. Lehmeier, June 2009

Sl. 4. Pristajanje kruzera u Kotoru. Fotografirao: H. Lehmeier, lipanj 2009. 
Not only hotels seek to attract wealthy customers; there are several other large tourism projects, for example, the newly constructed marina in Tivat (Uttrich 2009), the "Cubus Lux" project in Valdanos Bay close to Ulcinj, and a bigger Russian investment on the Zavala peninsula south of Budva. Considerable investments are needed for such large projects at this quality level. Usually they come from foreign investors or investment groups. They stand in clear contrast to the tourism of the $1990 \mathrm{~s}$, which was very much concentrated on the domestic (and/or Serbian) market.

Much is expected of these new structures for high-class tourism. It is not so much the direct income from the business with the richer tourists but, much more importantly, the positive effects on Montenegro's image, which could turn into an overall attractiveness for larger groups of tourists.

Currently, most of the tourists coming to Montenegro are looking for offers at the middle or lower price levels. Apart from the already mentioned "Yugoslavian-Style" hotels, they find a large number of private accommodation facilities. These establishments are run by smaller providers and families. The necessary private investments are realised in several ways; often additional income is gained by providing other services for tourists (e.g. car rental, restaurants or souvenir selling) or by working temporarily in other sectors of business - often abroad. The main problem for the small private providers is, as already mentioned, the nearly complete dependence on the short season. The high number of small accommodation facilities is not a new development for Montenegro. In Yugoslavian times, small pensions and partly rented holiday houses formed a large part of the available accommodation for tourists (Büschenfeld 1981, 65). This tendency continued during the 1990s. In 1997, there were 25,000 hotel beds in Montenegro, but 80,000 beds in private rooms and 90,000 in holiday apartments (DEG 2001, 4).

These structures remain until today, but we can observe a strong regional differentiation within the Montenegrin coastline. In the region around Ulcinj, with its Albanian-speaking population, small providers and holiday apartments are the dominant form of accommodation. There are only few bigger hotels or apartment-complexes in this region. Along the coastline between Sutomore and Budva, these bigger structures are more frequent. The main reason for that lies in the different costumer profiles. In the south, around Ulcinj, there are many less well-off tourists from Albania and Kosovo, while Budva and its surroundings attract the wealthier Serbian and Russian customers. The (more or less limited) possibilities for new buildings are also an issue. Especially in the Kotor Bay, generally only very few possibilities for accommodation can be found. This is also a consequence of the steep relief in the Bay, which leaves only few possible sites for new buildings.

\section{"BUDVARISATION" AS A PATTERN FOR PLANNING AND DEVELOPMENT OF SETTLEMENTS?}

Most of the Montenegrins agree that the economic effects of the recent growth in tourism are to be considered as positive. Especially the newly created jobs and the general increase of wealth are, without any doubt, very important points. But there are also critical opinions, especially regarding the visible changes in the landscape. Many things are seen as problematic issues. These are mainly damage to the natural environment - which is 
considered as one of the main potentials for tourism, the rapid and uncontrolled expansion of settled areas, the sometimes unbalanced ratio between prices and performance and the barely professional staff.

Budva has about 11,000 inhabitants and is mostly known for its beach tourism. Estimations of the municipality report a number of up to 130,000 guests per day in the main season. This proportion - which is, of course, also known from other tourist destinations - causes a lot of problems and conflicts. In the case of Budva, these are primarily the completely overstrained infrastructures of traffic, supply and disposal. The motorway (Jadranska Magistrala) leads directly through the town itself so that this problem is magnified by the transitory traffic. During the high season, shortfalls in the energy supply up to complete power breakdowns appear from time to time. Regarding problems with the fresh-water supply, the construction of a seawater desalination plant predicts an easing of tension in this aspect.

These supply shortfalls are mainly caused by informal and partly illegal buildings, which are not only limited to the narrow beach area but also gradually grow up the hills of Budva Polje (Fig. 5). Only a few of these structures are hotels, while most of them are multi-storied apartment-blocks, which are either built for self-use or for renting. This means that they were erected for speculative motives. Without any doubt, this was made

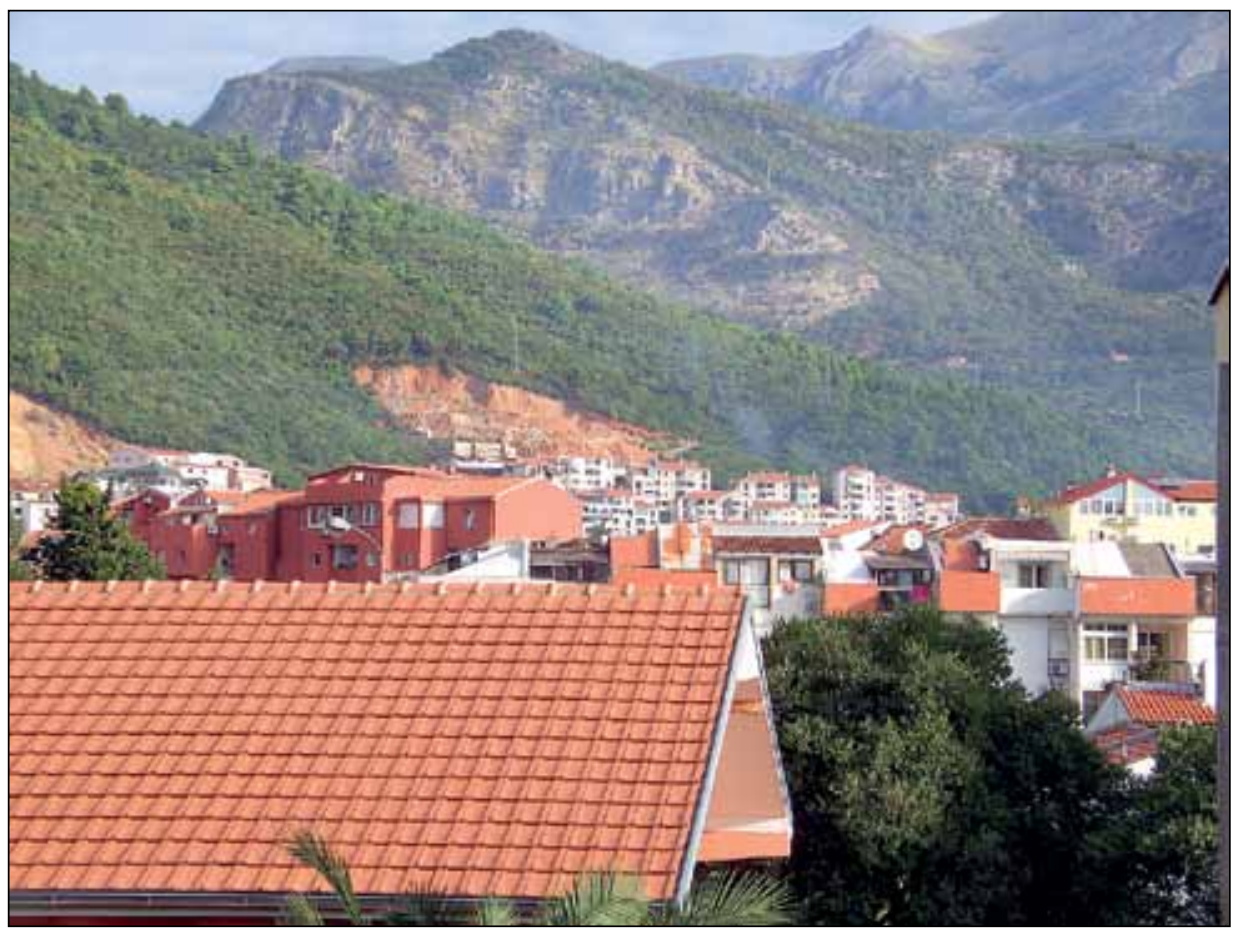

Fig. 5 During recent years, the partly informal settlement of apartment buildings has reached the surrounding hills of Budva; Photo: H. Lehmeier, October 2010

Sl. 5. Posljednjih godina nelegalna gradnja turističkih apartmana došla je i do okolice Budve. Fotografirao: H. Lehmeier, listopad 2010. 
possible due to lax practice of the planning institutions in the execution of the planning law. Admittedly, the valid urban spatial plan was - similarly to nearly everywhere in Montenegro - created during the time of former Yugoslavia, which means that it was just not possible to keep up with the latest requirements and demands in planning. Since 2008, an updated version of the urban spatial plan exists, at least for the inner urban area of Budva.

When speaking about the municipality of Kotor, these plans originate from the year 1995. But some informal structures could not be prohibited nonetheless - fewer in the historic old town itself than alongside the bay. This is why the planning institutions are mainly occupied with prohibiting the development of new informal settlements, which would be running contrary to the currently created new urban plan, as well as with the subsequent legalisation of older illegal buildings. Interestingly, informal building along the coastline of the former Yugoslavia is not a new phenomenon, but quite the contrary. Büschenfeld $(1981,70)$ already reported about tolerated forms of illegal settlements. So this way of informality can even be seen as a kind of tradition. The term "Budvarisation" was used for these negative consequences by some interviewees.

\section{PLANNING AND POTENTIALS}

The situation in Montenegro's southernmost tourism destination Ulcinj is also rather complex. On the one hand, the same problems as in other locations exist: e.g. lacking planning, infrastructure or legal security. The old town is divided into small sections and opens into a small bay area. New hotels and countless restaurants have been opened in many places there. But now, the available space is more or less exhausted; one of the last newly built structures is a mosque in close proximity to the beach.

On the other hand, a different, large scale approach to tourism potential can be observed. Based on the negative experience from other tourism destinations in Montenegro, a major opportunity for the country's development can be found only $4 \mathrm{~km}$ south of Ulcinj, on the Albanian border at Ada Bojana, which has been widely known throughout Europe for many years as a nudist camp. The key to Montenegro's tourism future could possibly lie there at a place named Velika Plaža. The $15 \mathrm{~km}$ long "Big Beach", barely utilised as yet, is the largest sandy beach area on the whole eastern Adriatic coastline. There seems to be new awareness of this uniqueness and there is even a masterplan already in existence for development of this beach area (DEG 2003). An area of about $19.5 \mathrm{~km}^{2}\left(14.5 \mathrm{~km}^{2}\right.$ without the Island of Ada) is available for sale (DEG 2003, 67). A tender was set up for implementation of this project as well as a variety of public relations initiatives (e.g. a website www.velikaplaza.info, which is run by the Ministry of Spatial Planning and Environment of Montenegro). While only the north-eastern part of the area is occupied by a 4-star-allinclusive-facility of the Spanish Iberostar hotel chain and some reversible beach bars, the plan is to build six hotel-groups and mixed forms of accommodation offering a total of 25,000 to 27,000 beds (Government of Montenegro w.d., 1). The tender also includes areas of leisure (e.g. a golf course, amusement park) and a bird-watching zone (Fig. 6).

This is still the situation today. With a price for the whole area of about $€ 1.2$ bn (of $€$ 1.0 bn without Ada Bojana) (Albrecht 2010, 86), after years of unsuccessful tendering, the current information on the website www.velikaplaza.info emphasises: "Since there were 
no applications submitted for participation in the Tender by 15 October 2009, the Tender Committee decided to cancel the Tender for Velika Plaža" (Ministry of Spatial Planning and Environment of Montenegro 2008-2011).

Both the potential chances and problems for a project like this are obvious: On the one hand, the natural conditions and possibilities are unique for today's Mediterranean area. Selling this as an entity offers big chances for a project of high profile, public interest and sustainable development. On the other hand, the size of this area is too large and expensive for most investors. There is only a small market for this kind of project. Together with still existing issues in infrastructure and the uncertain economic development of Montenegro, this causes a problematic reputation for the country itself.

\section{SECONDARY EFFECTS OF TOURISM}

Of course, the economic impact of tourism is not limited to accommodation. There are many possibilities to earn a living in other branches connected to the tourism industry. As for mass tourism destinations in general, a lot of other products and services are offered. Besides restaurants of varying levels of quality and miscellaneous establishments for night-time gastronomy, small businesses, especially, have to be kept in mind. Many entrepreneurs are working e.g. in car- and boat-rentals, souvenir selling or as tourist guides. The quantity and variety of employment possibilities created thereby can hardly be registered in statistics - not least because of the omnipresence of the informal economy.

The effects of seasonality cause a periodic need for working staff, which many businesses solve by employing seasonal-workers. These workers often come from Serbia or Bosnia- Herzegovina. While for many domestic people these jobs do not seem to be interesting due to salary reasons, citizens from neighbouring countries are gladly accepting these opportunities to earn money, as there is a significant lack of jobs in their countries of origin. In addition, for linguistic reasons, the possibility to go to the beach and participate in the nightlife during their spare time is of importance for many young seasonal workers.

The working opportunities along the coastline are a major draw. The result has been a growth of population in the coastal area, while the mountainous regions of northern and eastern Montenegro, especially, are exposed to an economic and demographic shrinking process. Only the capital Podgorica and its urban hinterland register a similar demographic growth from migration. In the shrinking regions - similarly known in other mountainous areas - ageing, regression of settlements and economic marginalisation are the elements of degradation in these locations. So internal migration in the direction of coastal areas or urban centres is not peculiar in Montenegro but is also typical for the whole Mediterranean area (Wagner 2001, 85). This has even been a spatial characteristic in socialist Yugoslavia (Büschenfeld 1981, 69f.). Nevertheless, this new wave of litoralisation is of wider scale.

During the Yugoslavian times, two large State-financed industrial facilities were built - the aluminium plant in Podgorica and the steel factory in Nikšić. Thus, the transition of the mainly agricultural economy of Montenegro towards an industrial country should be reenforced. Additionally, already existing tendencies towards a concentration of employment and population at the coastline should be mitigated. In fact, at the same time, the harbour in 


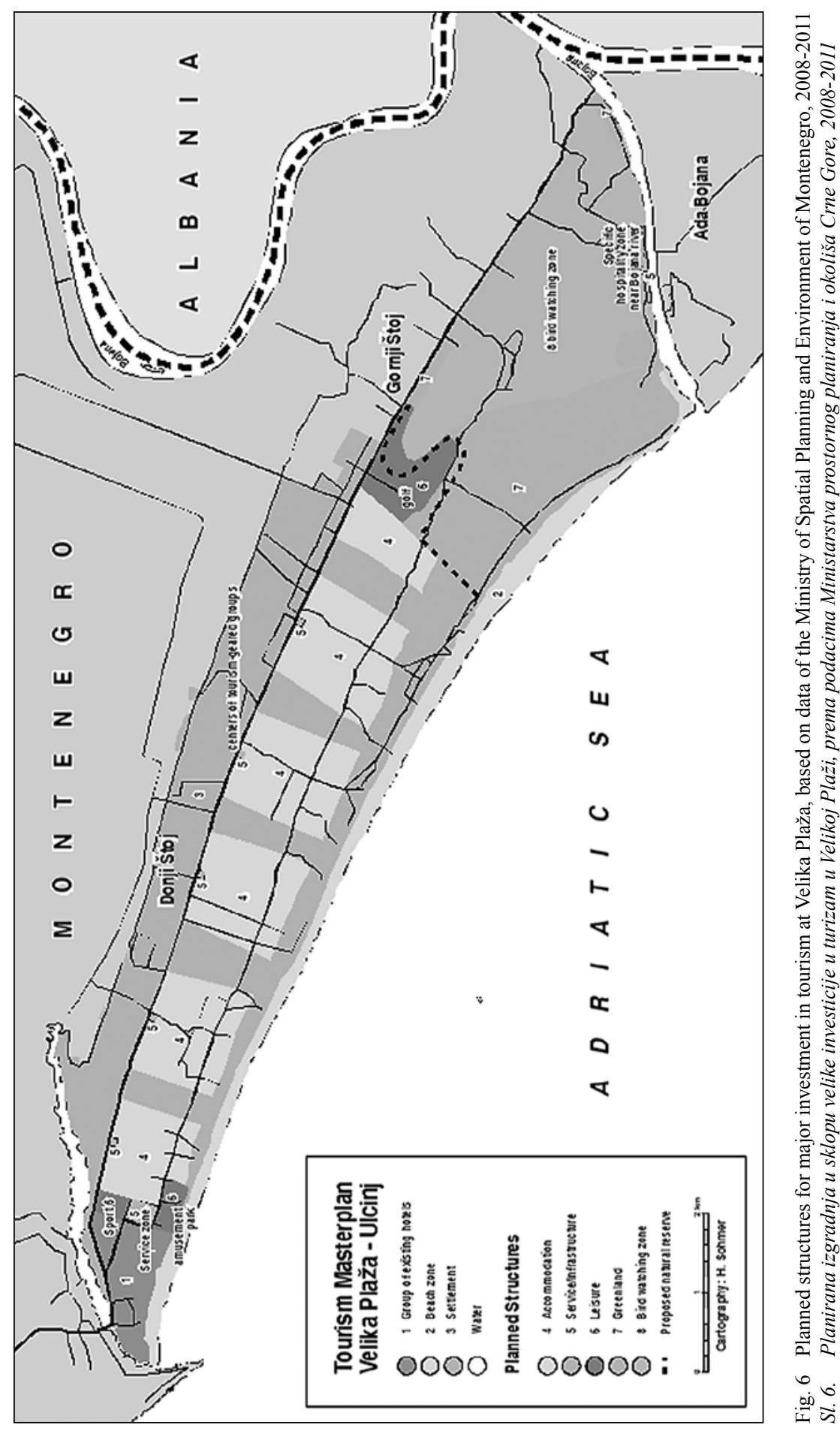


the town of Bar was also expanded, but those large, planned economical facilities in total diminished the attraction of the coastal area. Caused by the transition process, industrial production collapsed completely; during the 1990s GDP dropped by 50\%, while the relative percentage of services grew from 50\% to more than 70\% (Büschenfeld 2001, 50f.).

The extensive de-industrialisation not only reduced economic progress but also stopped many spatial development processes from socialist times. Some of them, which were leading to litoralisation, had been slowed down in socialist times; but now (since the turn of the millennium at the latest) they have been gaining speed again - fuelled by a constantly growing beach tourism industry. In this process, not only have places of residence been transferred to the coastal area; for many Montenegrins from the hinterland, investments in valuable tourism facilities are seen as a promising capital asset. Combined with longer stays abroad, three-staged biographies of migration can sometimes occur. After leaving the Montenegrin hinterland, a longer working stay abroad is utilised to accumulate sufficient funds for investment. After that, return migration to the Montenegrin coast is the next step.

\section{ACHIEVEMENTS AND MISTAKES}

The strengths of Montenegro as a tourism destination are well known and adequately advertised: diverse Nature, the variations in the coastline, a generally acceptable price level, the hospitable ambience, etc. Weaknesses are the under-assertive State and wide-spread of corruption and laissez-faire, leading to a more or less unavoidable process of informal development. In addition to this, environmental awareness is lacking and the coastline is clearly over-strained - from a cultural and natural point of view. Furthermore, the priceperformance ratio is disproportional in some locations and a locally distinct gold-rush attitude has appeared in recent years. It turns out that the strengths and unquestionable successes are endangered by these negative developments.

Another problem is the relative financial weakness of the domestic stakeholders. This affects, for example, the hotel facilities from Yugoslavian times. Although these structures are mostly built in an excellent location, their existence is insecure because of a slow privatisation process, an overstrained management and the poor state of the buildings. In the worst cases, the ruins of these buildings are blocking the best tourism spots, which can already be found on an impressive scale around the coastline of Budva. Otherwise, nearly all the new larger medium-class and especially the premium-class structures - facilities that are holiday resorts, all with a high standard and thus internationally competitive have been built with foreign investments. So, at least in the high-class sector, Montengrin tourism seems to be unable to exist without foreign participation and is consequently controlled from outside.

However, the "Yugoslavian legacy" also offers a distinct advantage: The staff is often well-trained - at least the permanent, established staff. A very dynamic entrepreneurship in the small business sector, not only in the accommodation business, should also be mentioned. Surprisingly, experiences from abroad or knowledge of foreign languages are not the standard. Where this is the case, it is definitely another competitive advantage.

In the global tourism markets, the "Montenegro product" is more and more well known and accepted in a positive way. For example, a preliminary report on the 2009 
season reports highly satisfied guests. This, in turn, results in a growing willingness to return (Ministry of Tourism, National Tourist Organisation 2009). Montenegro seems to have arrived (again) on the global tourism market and can optimistically look forward to future seasons.

\section{FINAL CONCLUSION AND FUTURE PROSPECTS}

Summing up, multiple polarisations and divergences accompany the overall dynamic and progressive developments (Fig. 7). The field of mass-tourism still needs a qualitative upgrade in many aspects. This demand can be met by optimising existing structures and offers. Additionally, there are exclusive opportunities on a larger scale (e.g. Velika Plaža), which still need an extensive investment.

So-called retirement migration, bringing elderly people to southern countries and mitigating the negative effects of seasonality, is still not an important issue in Montenegro. Examples from other countries (e.g. Breuer 2005) show that this can occur on a relevant scale and bring in new economic possibilities. This could be an interesting field for future research.

While the economic importance of the tourism industry for Montenegro's future is indisputable, the negative effects caused by mono-structuring and barely sustainable developments should be kept in mind.

\begin{tabular}{|c|c|}
\hline $\begin{array}{l}\text { Achievements: } \\
\text { international competitiveness of new middle- } \\
\text { class hotels } \\
\text { dynamic entrepreneurship in the small business } \\
\text { sector } \\
\text { growing knowledge of Montenegro as an inter- } \\
\text { national tourism destination } \\
\text { growing number of tourists }\end{array}$ & $\begin{array}{l}\text { Mistakes: } \\
\text { partially lacking offers of competitive high- } \\
\text { class standards } \\
\text { slow privatisation process } \\
\text { focus on coastal tourism } \\
\text { gold-rush-attitude } \\
\text { "Budvarisation" }\end{array}$ \\
\hline \begin{tabular}{|l|} 
Strengths: \\
diversity of Nature \\
variations of coastline \\
acceptable price level \\
hospitable ambience \\
partially well-trained staff
\end{tabular} & $\begin{array}{l}\text { Weaknesses: } \\
\text { the under-assertive State and wide-spread } \\
\text { corruption } \\
\text { informal developments } \\
\text { environmental issues } \\
\text { overstrained coastline } \\
\text { locally disproportional price-performance-ratio } \\
\text { wide-spread lack of foreign language skills }\end{array}$ \\
\hline $\begin{array}{l}\text { Opportunities: } \\
\text { exclusive spots on a larger scale (i.e. Velika } \\
\text { Plaža) } \\
\text { possibilities for diversification (i.e. mountains, } \\
\text { nature parks) } \\
\text { capacities for retirement migration } \\
\text { possibility for upgrade of offers in mass-tou- } \\
\text { rism }\end{array}$ & $\begin{array}{l}\text { Threats: } \\
\text { high dependency on foreign investors, esp. in } \\
\text { the field of high-class investments } \\
\text { increasing seasonality } \\
\text { insufficient sustainability } \\
\text { mono-structuring of the economy } \\
\text { increase of nation-wide spatial disparities }\end{array}$ \\
\hline
\end{tabular}

Fig. 7 Overview AMSWOT-analysis

Sl. 7. Pregled AMSWOT analize 
Coastal Tourism in Montenegro - Economic Dynamics, Spatial Developments and Future Perspectives

\section{REFERENCES}

Albrecht, R., 2010: Küstentourismus in Montenegro - Chancen und Potentiale der südmontenegrinischen Region um Ulcinj im internationalen Fremdenverkehr. Unpublished Diploma Thesis at the Department for Geography, Bamberg.

Bottlik, Z., 2008: Geographische Hintergründe zur nationalen Identität der Montenegriner, Geographische Rundschau 60(10), 54-60.

Breuer, T., 2005: Retirement Migration or rather Second-Home Tourism? German Senior Citizens on the Canary Islands, Die Erde 136(3), 313-333.

Büschenfeld, H., 1981: Jugoslawien, Länderprofile - Geographische Strukturen, Daten, Entwicklungen, Klett, Stuttgart.

Büschenfeld, H., 2001: Montenegro auf dem Weg in die Selbständigkeit. Geographische Rundschau 53(11), 48-53.

Crna Gora Ministarstvo Turizma I Zaštite Životne Sredine, 2008: Stratejia Razovja Turizma u Crnoj Gori do 2020. Godine, Podgorica.

DEG Deutsche Entwicklungsgesellschaft mbH (Ed.), 2001: Tourismus-Masterplan Montenegro. Integrierter regionaler Gesamtansatz zu Restrukturierung und Entwicklung des Tourismus in Kroatien und Montenegro, Cologne.

DEG Deutsche Entwicklungsgesellschaft mbH(Ed.), 2003: Räumliches Konzept für die touristische Entwicklung der Velika Plaža. Masterplan. Enddokument. Cologne.

Gosar, A., 2007: Razvojne karakteristike i izazivi turizma u Jugostočnoj Europi, s posebnim naglaskom na Sloveniju. Development Characteristics and Challenges of Tourism in Southeastern Europe, with Special Emphasis on Slovenia. Acta Turstica Nova 1(2), 127-154.

Government of Montenegro - Privatisation Council. Tender Commission for Tourism Development of Velika plaza, w.d.: Invitation for Expression of Interest, Podgorica.

Hall, D., 2004: Rejuvenation, Diversification and Imagery: Sustainability Conflicts for Tourism Policy in the Eastern Adriatic, in: Coastal Mass Tourism. Diversification and Sustainable Development in Southern Europe (Ed. Bramwell, B.), Aspects of Tourism 12, Channel View, Clevedon et al, 341-355.

Jordan, P., 2005a: Der Tourismus in Montenegro, in: Serbien und Montenegro. Raum und Bevölkerung - Geschichte - Sprache und Literatur - Kultur - Politik - Gesellschaft - Wirtschaft - Recht (Eds. Lukan, W., Trgovčević, L., Vukčević, D.), Osthefte: Sonderband 18, LIT, Vienna, Münster, 701-719.

Jordan, P., 2005b: The Impact of Foreign and Indigenous Capital in Rebuilding Croatia's Tourism Industry, in: Foreign Direct Investment and Regional Development in East Central Europe and the Former Soviet Union (Ed. Turnock, D.), Aldershot, 243-266.

Jordan, P., 2006: Tourismus als Entwicklungsfaktor? Tourismuspotenzial und Tourismusentwicklung im östlichen Europa, in: Europa und die Erweiterung der EU (Ed. Scheffer, J.), Passauer Kontaktstudium Erdkunde 8, Selbstverlag, Passau, 45-57.

Light, D., 2006: Romania: national identity, tourism promotion and European integration, in: Tourism in the New Europe: The Challenges and Opportunities of EU Enlargement (Eds. Hall, D., Smith, M., Marciszewska, B.), CABI, Wallingford, 256-269.

Mildner, K., 2009: Der westliche Balkan in den Fängen der Finanzkrise. Südosteuropa-Mitteilungen 01/2009, 6-15.

Ministarstvo Turizma Crne Gore u. Turistička Organizacija Crne Gore (Ed.), 2004: Turizam Crne Gore u drugoj polovini XX veka. Zbornik radova sa naučnog skupa na Cetinju 23-24 maj 2002. godine, Cetinje.

Ministry of Spatial Planning and Environment of Montenegro, 2008-2011, http://www.velikaplaza. info/?a=investors $(23.12 .2010)$.

Ministry of Tourism, National Tourist Organisation, 2009: Tourism Survey 2009, Podgorica, http://www.gov. me/eng/ (15.12.2010). 
MONSTAT Statistical Office of Montenegro, 2009: Annual Data - Tourism, http://www.monstat.org/Godisnji\%20 podaci/Godina2007/turizam\%202007/engturizam\%202007.htm (19.12.2010).

Strugar, B., 2007: Montenegro, Studio Strugar, Belgrade.

Uttich, S., 2009: Der Traum vom zweiten Monaco. Frankfurter Allgemeine Sonntagszeitung No. 16(19.04.2009), V13.

Wagner, H.-G., 2001: Mittelmeerraum, Wissenschaftliche Länderkunden, WBG, Darmstadt.

Winterhagen, J., 2008: Entscheidend ist die Strategie: Tourismusentwicklung und Migration in Plav, Montenegro. Diskussionspapier, ed. GTZ Deutsche Gesellschaft für technische Zusammenarbeit GmbH, Eschborn.

WTTC World Travel \& Tourism Council, 2009: Travel \& Tourism: Economic Impact. Montenegro. London.

WTTC World Travel \& Tourism Council, 2010: Travel \& Tourism: Economic Impact. Montenegro. London.

Received (Primljeno): $2011-01-14$

Accepted (Prihvaćeno): $2011-04-08$

\section{Dipl.-Geograph Matthias Bickert}

Department of Geography, University of Bamberg Geographical Research on Migration and Transition Am Kranen 12, 96045 Bamberg, Germany matthias.bickert@uni-bamberg.de

\section{Prof. Dr. Daniel Göler}

Department of Geography, University of Bamberg Geographical Research on Migration and Transition Am Kranen 12, 96045 Bamberg, Germany daniel.goeler@uni-bamberg.de

Dipl.-Geograph Holger Lehmeier

Department of Geography, University of Bamberg Geographical Research on Migration and Transition Am Kranen 12, 96045 Bamberg, Germany holger.lehmeier@uni-bamberg.de 